\title{
Improved stability, insulin-releasing activity and antidiabetic potential of two novel $N$-terminal analogues of gastric inhibitory polypeptide: $\mathbf{N}$-acetyl-GIP and pGlu-GIP
}

\author{
F. P. M. O'Harte ${ }^{1}$, V. A. Gault ${ }^{1}$, J. C. Parker ${ }^{1}$, P. Harriott ${ }^{2}$, M. H. Mooney ${ }^{1}$, C. J. Bailey ${ }^{3}$, P. R. Flatt ${ }^{1}$ \\ ${ }^{1}$ School of Biomedical Sciences, University of Ulster, Coleraine, N. Ireland, UK \\ 2 Centre for Peptide and Protein Engineering, School of Biology and Biochemistry, The Queen's University of Belfast, \\ Belfast, N. Ireland, UK \\ ${ }^{3}$ School of Pharmaceutical and Biological Sciences, Aston University, Birmingham, UK
}

\section{Abstract}

Aims/hypothesis. This study examined the plasma stability, biological activity and antidiabetic potential of two novel N-terminally modified analogues of gastric inhibitory polypeptide (GIP).

Methods. Degradation studies were carried out on GIP, N-acetyl-GIP (Ac-GIP) and N-pyroglutamyl-GIP (pGlu-GIP) in vitro following incubation with either dipeptidylpeptidase IV or human plasma. Cyclic adenosine $3^{\prime} 5^{\prime}$ monophosphate (cAMP) production was assessed in Chinese hamster lung fibroblast cells transfected with the human GIP receptor. Insulin-releasing ability was assessed in vitro in BRIN-BD11 cells and in obese diabetic $(o b / o b)$ mice.

Results. GIP was rapidly degraded by dipeptidylpeptidase IV and plasma (t $\mathrm{t}^{1 / 2} 2.3$ and $6.2 \mathrm{~h}$, respectively) whereas Ac-GIP and pGlu-GIP remained intact even after $24 \mathrm{~h}$. Both Ac-GIP and pGlu-GIP were extremely potent $(p<0.001)$ at stimulating cAMP production $\left(\mathrm{EC}_{50}\right.$ values 1.9 and $2.7 \mathrm{nmol} / \mathrm{l}$, respectively), almost a tenfold increase compared to native GIP $(18.2 \mathrm{nmol} / \mathrm{l})$. Both Ac-GIP and pGlu-GIP $\left(10^{-13}-10^{-8} \mathrm{mmol} / \mathrm{l}\right)$ were more potent at stimulating insulin release compared to the native GIP $(p<0.001)$, with 1.3-fold and 1.2-fold increases observed at $10^{-8} \mathrm{~mol} / \mathrm{l}$, respectively. Administration of GIP analogues ( $25 \mathrm{nmol} / \mathrm{kg}$ body weight, i.p.) together with glucose $(18 \mathrm{mmol} / \mathrm{kg})$ in $(o b / o b)$ mice lowered $(p<0.001)$ individual glucose values at $60 \mathrm{~min}$ together with the areas under the curve for glucose compared to native GIP. This antihyperglycaemic effect was coupled to a raised $(p<0.001)$ and more prolonged insulin response after administration of Ac-GIP and pGlu-GIP (AUC, $644 \pm 54$ and $576 \pm 51 \mathrm{ng} \cdot \mathrm{ml}^{-1} \cdot \mathrm{min}$, respectively) compared with native GIP (AUC, $257 \pm 29 \mathrm{ng} \cdot \mathrm{ml}^{-1} \cdot \mathrm{min}$ ). Conclusion/interpretation. Ac-GIP and pGlu-GIP, show resistance to plasma dipeptidylpeptidase IV degradation, resulting in enhanced biological activity and improved antidiabetic potential in vivo, raising the possibility of their use in therapy of Type II (non-insulin-dependent) diabetes mellitus. [Diabetologia (2002) 45:1281-1291]

Keywords GIP analogues, antihyperglycaemic effects, insulin secretion, DPP IV stability, BRIN-BD11 cells, obese hyperglycaemic $(o b / o b)$ mice.
Received: 25 February 2002 / Revised: 23 April 2002

Published online: 16 July 2002

(C) Springer-Verlag 2002

Corresponding author: Dr. F. P. M. O'Harte, School of Biomedical Sciences, University of Ulster, Coleraine, N. Ireland, UK, BT52 1SA, E-mail: fpm.oharte@ulst.ac.uk

Abbreviations: cAMP, Cyclic adenosine 3' 5' monophosphate; DPP IV, Dipeptidylpeptidase IV; GIP, gastric inhibitory polypeptide; GLP-1, glucagon-like peptide-1(7- 36)amide; TFA, trifluoroacetic acid; ESI-MS, electrospray ionisation mass spectrometry; pGlu, N-pyroglutamyl; Ac, N-acetyl; Fmoc, 9-fluorenylmethoxycarbonyl; CHL, Chinese hamster lung fibroblast; DPA, diprotin A; FSK, forskolin; IBMX, isobutylmethylxanthine
Type II (non-insulin-dependent) diabetes mellitus is characterised by a decreased responsiveness of peripheral tissues to insulin and a diminished and delayed pancreatic beta-cell response to glucose $[1,2]$. Therefore, novel therapeutic agents that normalise the betacell response to glucose are of considerable interest in the treatment of Type II diabetes. Two candidate agents including gastric inhibitory polypeptide (GIP) also called glucose-dependent insulinotropic polypeptide, together with the structurally related glucagonlike peptide-1(7-36)amide (GLP-1), act as major insulin-releasing hormones through the enteroinsular axis 
$[3,4]$. Considerable interest has already been invested in GLP-1 as a potential therapeutic candidate $[4,5,6$, 7].

Although both GIP and GLP-1 possess important insulinotropic properties [4], controversy exists regarding their relative effectiveness in stimulating insulin release. Some studies have shown that GIP and GLP-1 are equally potent in their capacity to stimulate insulin release [8], whereas others have suggested that GLP-1 possesses greater insulinotropic activity [9, 10]. Another study [11] indicated that GIP and GLP-1 are equally insulinotropic and share the same glucose threshold for activity; however, at the concentrations found postprandially, GIP is likely to be the more important incretin.

Further insight can be gained by examining glucose tolerance in GLP-1 receptor negative and GIP receptor negative animal models. GLP-1 receptor negative (GLP-1R -/-) mice show only modest glucose intolerance [12]. It has been shown that GLP-1R -/- mice have compensatory changes in the enteroinsular axis via increased GIP secretion and enhanced GIP action [12]. Serum GIP concentrations in GLP-1R -/- mice were increased compared with those in GLP-1R +/+ control mice after an OGTT. In contrast, studies with GIP receptor negative (GIPR -/-) mice have shown that these animals have higher blood glucose concentrations with impaired first phase insulin response [13]. The response of GIPR -/- mice to an intraperitoneal glucose tolerance test was similar to GIPR +/+ mice but glucose intolerance was present in the former group after an OGTT [13].

One of the key obstacles in utilising insulinotropic and antihyperglycaemic activity of GIP [14] as a potential therapy for diabetes is the short circulating half-life of the peptide (approximately 3-5 $\mathrm{min}$ ) in the plasma $[15,16]$. As with GLP-1 degradation, this is due mainly to rapid cleavage by a highly specific aminopeptidase, dipeptidyl peptidase IV (DPP IV; EC.3.4.14.5) a member of the prolyl oligopeptidase family of serine proteases [17]. DPP IV is expressed ubiquitously in mammalian tissues and organs [18] with a specificity for removing dipeptides from the amino terminus of a wide range of peptides with penultimate proline, alanine and hydroxyproline residues $[19,20]$. DPP IV is in close contact with hormones circulating in the blood, located on endothelial cells of the blood vessels and, moreover, it is found as a soluble enzyme in blood plasma [21]. Thus DPP IV removes the amino-terminal $\mathrm{Tyr}^{1}-\mathrm{Ala}^{2}$ dipeptide from GIP producing GIP(3-42) [22]. This truncated peptide was initially believed to be biologically inactive; however, current opinion suggests that it could operate as a GIP receptor antagonist, thus preventing normal receptor interaction with the intact hormone [23]. Consistent with these observations, it has been shown that inhibition of DPP IV activity can potentiate the insulinotropic effect of GIP in mammals [24].
Recent studies in our laboratory have shown that N-terminal modification of GIP and GLP-1 by glycation results in resistance to DPP IV and confers an extended plasma half-life $[25,26]$. N-terminally modified GIP could have a particularly promising potential as an antihyperglycaemic agent because its glucose lowering and insulin-releasing properties seem to be enhanced by this modification [27]. Our study was designed to investigate the stability and biological activity of two novel N-terminally modified analogues of GIP, namely Ac-GIP and pGluGIP. In addition to degradation studies and observations of cyclic AMP production and insulin secretion in vitro, the utility of these analogues has been clearly established in vivo using obese diabetic (ob/ob) mice as a commonly used animal model of Type II diabetes having both beta-cell dysfunction and insulin resistance.

\section{Materials and methods}

Materials. High-performance liquid chromatography (HPLC) grade acetonitrile was obtained from Rathburn (Walkersburn, Scotland, UK). Sequencing grade trifluoroacetic acid (TFA) was obtained from Aldrich (Poole, Dorset, UK). Dipeptidyl peptidase IV (DPP IV), isobutylmethylxanthine (IBMX), adenosine $3^{\prime}: 5^{\prime}$-cyclic monophosphate (cAMP), adenosine 5'-triphosphate (ATP) were all purchased from Sigma (Poole, Dorset, UK). Fmoc-protected amino acids and diprotin A were from Calbiochem Novabiochem (Beeston, Nottingham, UK). RPMI 1640 and DMEM tissue culture medium, foetal bovine serum, penicillin and streptomycin were all purchased from Gibco (Paisley, Strathclyde, Scotland). The chromatography columns used for cAMP assay, Dowex AG $50 \mathrm{WX}$ and neutral alumina AG7 were obtained from Bio-Rad (Alpha Analytical, Larne, N. Ireland, UK). All water used in these experiments was purified using a Milli-Q, Water Purification System (Millipore, Milford, Mass., USA). All other chemicals used were of the highest purity available.

Synthesis of GIP, Ac-GIP and pGlu-GIP. GIP, Ac-GIP and pGlu-GIP were sequentially synthesised on an Applied Biosystems automated peptide synthesiser (model 432A, Foster City, Calif., USA) using standard solid-phase Fmoc protocols [28], starting from a pre-loaded Fmoc-Gln-Wang resin. The following side chain protected amino acids were used, FmocGln(Trt)-OH, Fmoc-Thr(Trt)-OH, Fmoc-His(Trt)-OH, FmocAsn(Trt)-OH, Fmoc-Ser(Trt)-OH, Fmoc-Lys(Boc)-OH, FmocTrp(Boc)-OH, Fmoc-Asp(OtBu)-OH, Fmoc-Tyr(OtBu)-OH and Pyr-OH. In the case of Ac-GIP acetic anhydride was added to the growing chain in the final step prior to cleavage from the resin. Deprotection and cleavage of the peptide from the resin was by trifluoroacetic acid:water:thianisole:ethanediol (90:2.5:5:2.5, a total volume of $20 \mathrm{ml} / \mathrm{g}$ resin), the resin was removed by filtration and the filtrate volume was decreased under reduced pressure. Dry diethyl ether was slowly added until a precipitate was observed. The precipitate was collected by low-speed centrifugation, resuspended in diethyl ether and centrifuged again, the procedure was carried out five times. The resulting pellets were then dried in vacuo and judged pure by reversed-phase HPLC on a Waters Millennium 2010 chromatography system (Millford, Mass., USA) Software version 2.1.5. 
Structural confirmation of GIP and GIP analogues by electrospray ionisation-mass spectrometry (ESI-MS). Intact and degradation fragments of GIP, Ac-GIP and pGlu-GIP were dissolved (approximately $400 \mathrm{pmol} / \mathrm{l}$ ) in $100 \mu \mathrm{l}$ of water and applied to an LCQ benchtop LC mass spectrometer (Finnigan MAT, Hemel Hempstead, UK). Samples (20 $\mu$ l direct loop injection) were applied at a flow rate of $0.2 \mathrm{ml} / \mathrm{min}$, under isocratic conditions in 35\% (v/v) acetonitrile/water. Mass spectra were obtained from the quadripole ion trap mass analyser and spectra collected using full ion scan mode over the mass-tocharge $(\mathrm{m} / \mathrm{z})$ range $150-2000$. The molecular masses of each fragment were calculated using prominent multiple charged ions using the following equation; $M_{r}=i M_{i}-i M_{h}$ (where $M_{r}$ is molecular mass; $M_{i}$ is $\mathrm{m} / \mathrm{z}$ ratio; $i$ is the number of charges; and $\mathrm{M}_{\mathrm{h}}$ is the mass of a proton).

Degradation of GIP, Ac-GIP and pGlu-GIP by DPP IV and human plasma. HPLC-purified GIP, Ac-GIP and pGlu-GIP were incubated in vitro at $37^{\circ} \mathrm{C}$ in $50 \mathrm{mmol} / 1$ triethanolamine$\mathrm{HCl}$, (pH 7.8, final peptide concentration $2 \mathrm{mmol} / \mathrm{l})$ with either DPP IV $(5 \mathrm{mU})$ or pooled human plasma $(10 \mu \mathrm{l})$ for $0,2,4$ and $8 \mathrm{~h}$. A 24-h plasma incubation was also carried out for each peptide in the presence of diprotin A $(5 \mathrm{mU})$. The enzymatic reaction was stopped by adding $10 \mu \mathrm{l}$ of $10 \%$ (v/v) TFA/water. The terminated reaction products were then applied to a Vydac C-18 column $(4.6 \times 250 \mathrm{~mm})$ and the major degradation fragment GIP(3-42) separated from intact GIP. The column was equilibrated with $0.12 \%(\mathrm{v} / \mathrm{v}) \mathrm{TFA} /$ water at a flow rate of $1.0 \mathrm{ml} / \mathrm{min}$. Using $0.1 \%$ (v/v) TFA in $70 \%$ acetonitrile/water, the concentration of acetonitrile in the eluting solvent was raised from $0 \%$ to $28 \%$ over $10 \mathrm{~min}$, and from $28 \%$ to $42 \%$ over $20 \mathrm{~min}$. The absorbance was monitored at $206 \mathrm{~nm}$ using a Spectrasystem UV 2000 detector (Thermoquest Limited, Manchester, UK) and peaks were collected manually prior to ESIMS analysis. The small decline of GIP analogue peak area in some extended incubations, is likely to reflect non-specific binding to the incubation tube.

Cells and cell culture. Chinese hamster lung fibroblast (CHL) cells transfected with human GIP receptor [29] were cultured in DMEM tissue culture medium containing $10 \%(\mathrm{v} / \mathrm{v})$ foetal bovine serum, $1 \%(\mathrm{v} / \mathrm{v})$ antibiotics $(100 \mathrm{U} / \mathrm{ml}$ penicillin, $0.1 \mathrm{mg} / \mathrm{ml}$ streptomycin). BRIN-BD11 cells were cultured in sterile tissue culture flasks (Corning, Glass Works, Sunderland, UK) using RPMI-1640 tissue culture medium containing $10 \%$ $(\mathrm{v} / \mathrm{v})$ foetal calf serum, $1 \%(\mathrm{v} / \mathrm{v})$ antibiotics $(100 \mathrm{U} / \mathrm{ml}$ penicillin, $0.1 \mathrm{mg} / \mathrm{ml}$ streptomycin) and $11.1 \mathrm{mmol} / 1$ glucose. The origin, characteristics and secretory responsiveness of this electrofusion-derived glucose-responsive cell line has been described in detail elsewhere [30]. The cells were maintained at $37^{\circ} \mathrm{C}$ in an atmosphere of $5 \% \mathrm{CO}_{2}$ and $95 \%$ air using a LEEC incubator (Laboratory Technical Engineering, Nottingham, UK). It was confirmed that there was no significant degradation of native GIP in acute incubations with CHL cells or BRIN-BD11 cells under the experimental conditions described below.

Determination of cAMP production in transfected $C H L$ cells. Chinese hamster lung fibroblast (CHL) cells stably transfected with the human GIP receptor were seeded into 12-multiwell plates (Nunc, Roskilde, Denmark) at a density of $1.0 \times 10^{5}$ cells per well [29]. The cells were then allowed to grow for $48 \mathrm{~h}$ before being exposed to $2 \mu \mathrm{Ci}$ of tritiated adenine (TRK311, Amersham, Buckinghamshire, UK) in $1 \mathrm{ml}$ DMEM, with $0.5 \%(\mathrm{w} / \mathrm{v})$ foetal bovine serum, and incubated at $37^{\circ} \mathrm{C}$ for 5 to $6 \mathrm{~h}$. The cells were then washed twice with Hanks' balanced salt solution (HBSS; $130 \mathrm{mmol} / \mathrm{l} \mathrm{NaCl}, 20 \mathrm{mmol} / \mathrm{l}$
HEPES, pH 7.4, $0.9 \mathrm{mmol} / \mathrm{l} \mathrm{NaHPO}_{4}, 0.8 \mathrm{mmol} / \mathrm{l} \mathrm{MgSO}_{4}$, $5.4 \mathrm{mmol} / \mathrm{l} \mathrm{KCl}, 1.8 \mathrm{mmol} / 1 \mathrm{CaCl}_{2}, 25 \mathrm{mmol} / \mathrm{l}$ glucose, $25 \mu \mathrm{mol} / \mathrm{l}$ phenol red). The cells were then exposed to varying concentrations $\left(10^{-12}\right.$ to $\left.10^{-6} \mathrm{~mol} / \mathrm{l}\right)$ of GIP, Ac-GIP, pGlu-GIP or forskolin (FSK) $(10 \mu \mathrm{mol} / \mathrm{l})$ in $\mathrm{HBSS}$, in the presence of $1 \mathrm{mmol} / \mathrm{l} \mathrm{IBMX}$, for 10 to $15 \mathrm{~min}$ at $37 \mathrm{C}$. The medium was subsequently removed and the cells lysed with $1 \mathrm{ml}$ of $5 \%$ trichloroacetic acid (TCA) containing $0.1 \mathrm{mmol} / 1$ unlabelled cAMP and $0.1 \mathrm{mmol} / 1$ unlabelled ATP. The intracellular tritiated cAMP was then separated on Dowex and alumina exchange resins as described previously [31].

Acute tests for insulin secretion. Before experimentation, BRIN-BD11 cells were harvested from the surface of the tissue culture flasks with the aid of trypsin-EDTA (Gibco), seeded into 24-multiwell plates (Nunc, Roskilde, Denmark) at a density of $1.0 \times 10^{5}$ cells per well, and allowed to attach overnight at $37^{\circ} \mathrm{C}$. Acute tests for insulin release were preceded by $40 \mathrm{~min}$ pre-incubation at $37^{\circ} \mathrm{C}$ in $1.0 \mathrm{ml}$ Krebs Ringer bicarbonate buffer $\left(115 \mathrm{mmol} / \mathrm{l} \mathrm{NaCl}, 4.7 \mathrm{mmol} / \mathrm{l} \mathrm{KCl}, 1.28 \mathrm{mmol} / \mathrm{l} \mathrm{CaCl}{ }_{2}\right.$, $1.2 \mathrm{mmol} / 1 \mathrm{KH}_{2} \mathrm{PO}_{4}, 1.2 \mathrm{mmol} / 1 \mathrm{MgSO}_{4}, 10 \mathrm{mmol} / 1 \mathrm{NaHCO}_{3}$, containing $0.5 \%(\mathrm{w} / \mathrm{v})$ bovine serum albumin, $\mathrm{pH}$ 7.4) supplemented with $1.1 \mathrm{mmol} / \mathrm{l}$ glucose. Test incubations were carried out $(n=8)$ in $5.6 \mathrm{mmol} / \mathrm{l}$ glucose with a range of concentrations $\left(10^{-13}\right.$ to $\left.10^{-8} \mathrm{~mol} / \mathrm{l}\right)$ of GIP, Ac-GIP and pGlu-GIP. After 20 min incubation, the buffer was removed from each well and aliquots $(200 \mu \mathrm{l})$ were used for measurement of insulin by radioimmunoassay [32].

In vivo biological activities of GIP, Ac-GIP and pGlu-GIP in obese diabetic (ob/ob) mice. Effects of GIP, Ac-GIP and pGluGIP on plasma glucose and insulin concentrations were examined using 14 to 18 -week-old obese diabetic $(o b / o b)$ mice. The genetic background and characteristics of the colony used have been outlined in detail elsewhere [33]. The animals were housed individually in an air-conditioned room at $22 \pm 2{ }^{\circ} \mathrm{C}$ with a 12 -h light to 12 -h dark cycle. Drinking water and a standard rodent maintenance diet (Trouw Nutrition, Cheshire, UK) were freely available. Plasma glucose and insulin responses were evaluated in 18-h fasted $(o b / o b)$ mice after an intraperitoneal (i.p.) injection of saline $(0.9 \%(\mathrm{w} / \mathrm{v}) \mathrm{NaCl})$ as control, glucose alone (18 mmol/kg body weight) or in combination with GIP, Ac-GIP or pGlu-GIP ( $25 \mathrm{nmol} / \mathrm{kg})$. All test solutions were administered in a final volume of $8 \mathrm{ml} / \mathrm{kg}$ body weight. Blood samples were collected from the cut tip of the tail of conscious mice into chilled fluoride-heparin microcentrifuge tubes (Sarstedt, Nümbrecht, Germany) immediately before injection $(t=0)$ and at 15, 30 and 60 min after injection. Plasma was separated by centrifugation using a Beckman microcentrifuge (Beckman Instruments, UK; for $30 \mathrm{~s}$ at $13000 \mathrm{~g}$ ) and stored at $-20^{\circ} \mathrm{C}$ prior to glucose and insulin measurements. The "Principles of Laboratory Animal Care" (NIH publication 1985) were followed and all animal studies were carried out in accordance with the UK Animals (Scientific Procedures) Act 1986.

Assessment of plasma glucose and insulin concentrations. Glucose was assayed by an automated glucose oxidase procedure using a Beckman Glucose Analyser II [34]. Insulin was assessed by dextran-charcoal RIA as described previously [32]. Incremental areas under plasma glucose and insulin curves (AUC) were calculated using a computer generated program (CAREA) using the trapezoidal rule [35] with baseline subtraction.

Statistical analysis. Results are expressed as means \pm SEM. Data were compared using the Student's $t$ test or ANOVA, followed by the Student-Newman-Keuls test. Groups of data from 

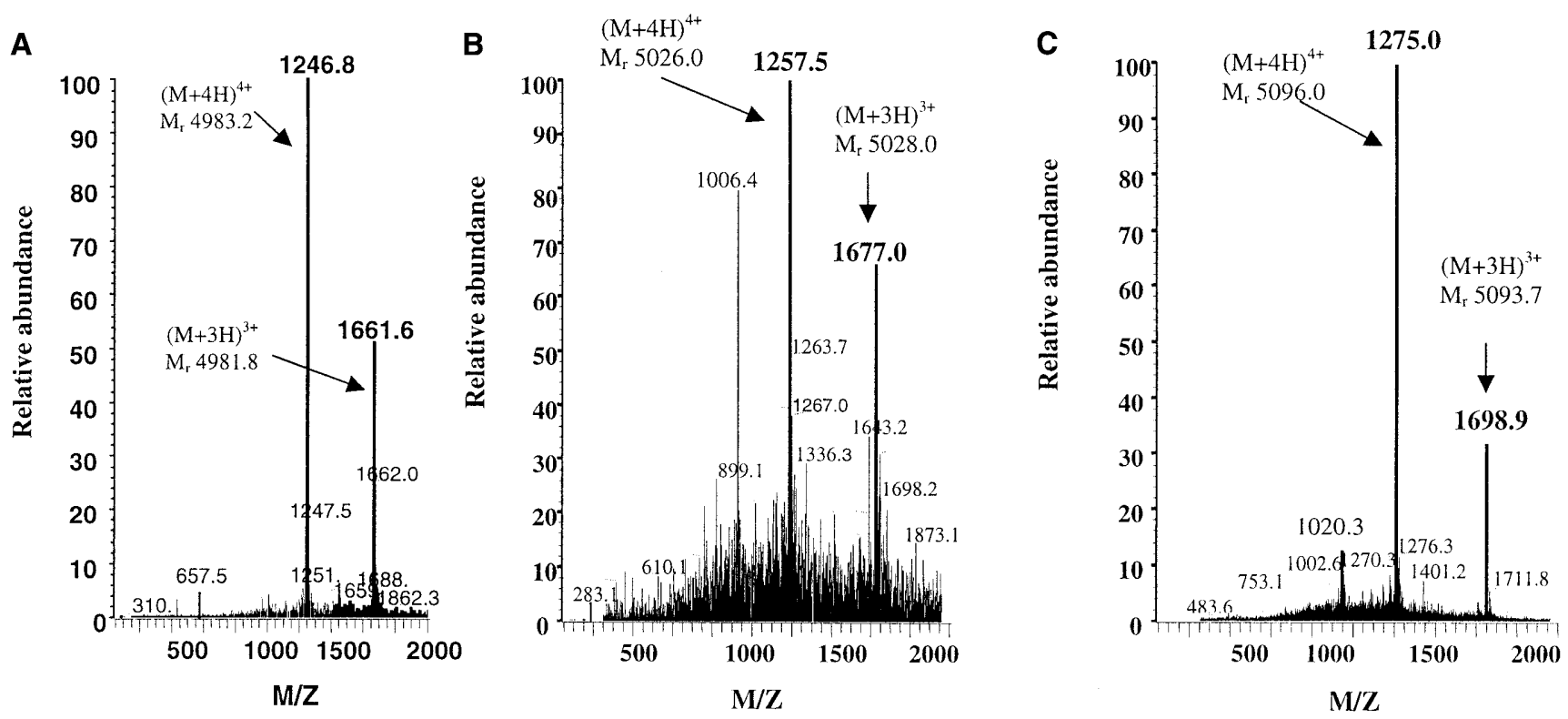

Fig. 1 A-C. Electrospray ionisation mass spectrometry of A human GIP(1-42), B N-acetyl-GIP and C N-pyroglutamyl-GIP, respectively. The peptides were applied by direct loop injection to the LC/MS under isocratic conditions. Spectra were recorded using a quadripole ion trap mass analyser and collected using full ion scan mode over the mass-to-charge $(\mathrm{m} / \mathrm{z})$ range $150-2000$

both were considered to be significantly different if the $p$ value was less than 0.05 .

\section{Results}

Structural identification of GIP, Ac-GIP and pGluGIP by ESI-MS. GIP, Ac-GIP and pGlu-GIP were produced by solid-phase peptide synthesis using standard Fmoc chemistry protocols. Following further purification on a Vydac C-18 analytical column $(4.6 \times 250 \mathrm{~mm})$, the monoisotopic molecular mass of each peptide was calculated using ESI-MS (Fig. 1). After spectral averaging was carried out, prominent multiple charged species $(\mathrm{M}+3 \mathrm{H})^{3+}$ and $(\mathrm{M}+4 \mathrm{H})^{4+}$ were detected for GIP at $\mathrm{m} / \mathrm{z} 1661.6$ and 1246.8 , corresponding to intact $\mathrm{M}_{\mathrm{r}} 4981.8$ and $\mathrm{M}_{\mathrm{r}}$ 4983.2 Daltons (Da), respectively (theoretical mass $4980.5 \mathrm{Da}$ ) (Fig. 1A). For Ac-GIP, $(\mathrm{M}+3 \mathrm{H})^{3+}$ and $(\mathrm{M}+4 \mathrm{H})^{4+}$ were detected at $\mathrm{m} / \mathrm{z} 1677.0$ and 1257.5 , corresponding to intact molecular masses of $\mathrm{M}_{\mathrm{r}} 5028.0$ and 5026.0 Da, respectively (Fig. 1B), corresponding very closely with the theoretical mass of 5026.2 Da. Similarly, for pGlu-GIP, $(\mathrm{M}+3 \mathrm{H})^{3+}$ and $(\mathrm{M}+4 \mathrm{H})^{4+}$ were detected at $\mathrm{m} / \mathrm{z} 1698.9$ and 1275.0 , corresponding to intact $\mathrm{M}_{\mathrm{r}} 5093.7$ and 5096.0 Da, respectively (Fig. 1C), which corresponds closely with the theoretical mass of 5094.2 Da. Results from the ESI-MS analysis showed that the correct primary structures for GIP and related analogues had been successfully synthesised.

Degradation of GIP, Ac-GIP and pGlu-GIP by DPP $I V$ and plasma. Figures 2, 3 and 4 show typical HPLC peak profiles obtained after separation of the reaction products obtained from the incubation of GIP, Ac-GIP and pGlu-GIP with DPP IV and plasma for 0, 2 and $8 \mathrm{~h}$. The HPLC retention times of GIP, Ac-GIP and pGlu-GIP incubated with DPP IV at $t=0$ were 21.72, 22.82 and $37.52 \mathrm{~min}$, respectively. Degradation of GIP (Fig. 2A) was evident after just $2 \mathrm{~h}$, which was indicated by a peak with a retention time of $20.81 \mathrm{~min}$, which upon ESI-MS analysis corresponded to GIP(3-42) (observed mass 4748.7 Da compared with theoretical mass $4746.4 \mathrm{Da}$ ). After 8 h, GIP (Fig. 2A) was completely degraded. In contrast, Ac-GIP and pGlu-GIP remained intact for more than $8 \mathrm{~h}$ (Fig. 3A, Fig. 4A). These peptides remained fully intact even after incubation was prolonged to $24 \mathrm{~h}$. Incubation with DPP IV showed that the relative in vitro halflives of GIP, Ac-GIP and pGlu-GIP were $2.3 \mathrm{~h},>24$ and $>24 \mathrm{~h}$, respectively.

In plasma degradation studies, retention times for intact GIP (Fig. 2B), Ac-GIP (Fig. 3B) and pGlu-GIP (Fig. 4B) were 21.94, 22.75 and $35.92 \mathrm{~min}$, respectively. Retention times for the major degradation fragment from native GIP, GIP(3-42) was $20.21 \mathrm{~min}$. In general, the degradation with human plasma was not as rapid as with purified DPP IV with $61 \%$ of GIP degraded by $8 \mathrm{~h}$ (Fig. 2A). The native peptide was completely degraded by $24 \mathrm{~h}$, an effect totally inhibited by DPA. In contrast, Ac-GIP (Fig. 3B) and pGlu-GIP (Fig. 4B) were not degraded by plasma incubation. In human plasma, the estimated half-lives of GIP, AcGIP and pGlu-GIP were $6.2 \mathrm{~h},>24 \mathrm{~h}$ and $>24 \mathrm{~h}$, respectively.

Effects of GIP, Ac-GIP and pGlu-GIP on cAMP production. Figure 5 shows the dose-dependent stimulation of cAMP production by GIP, Ac-GIP and pGlu- 

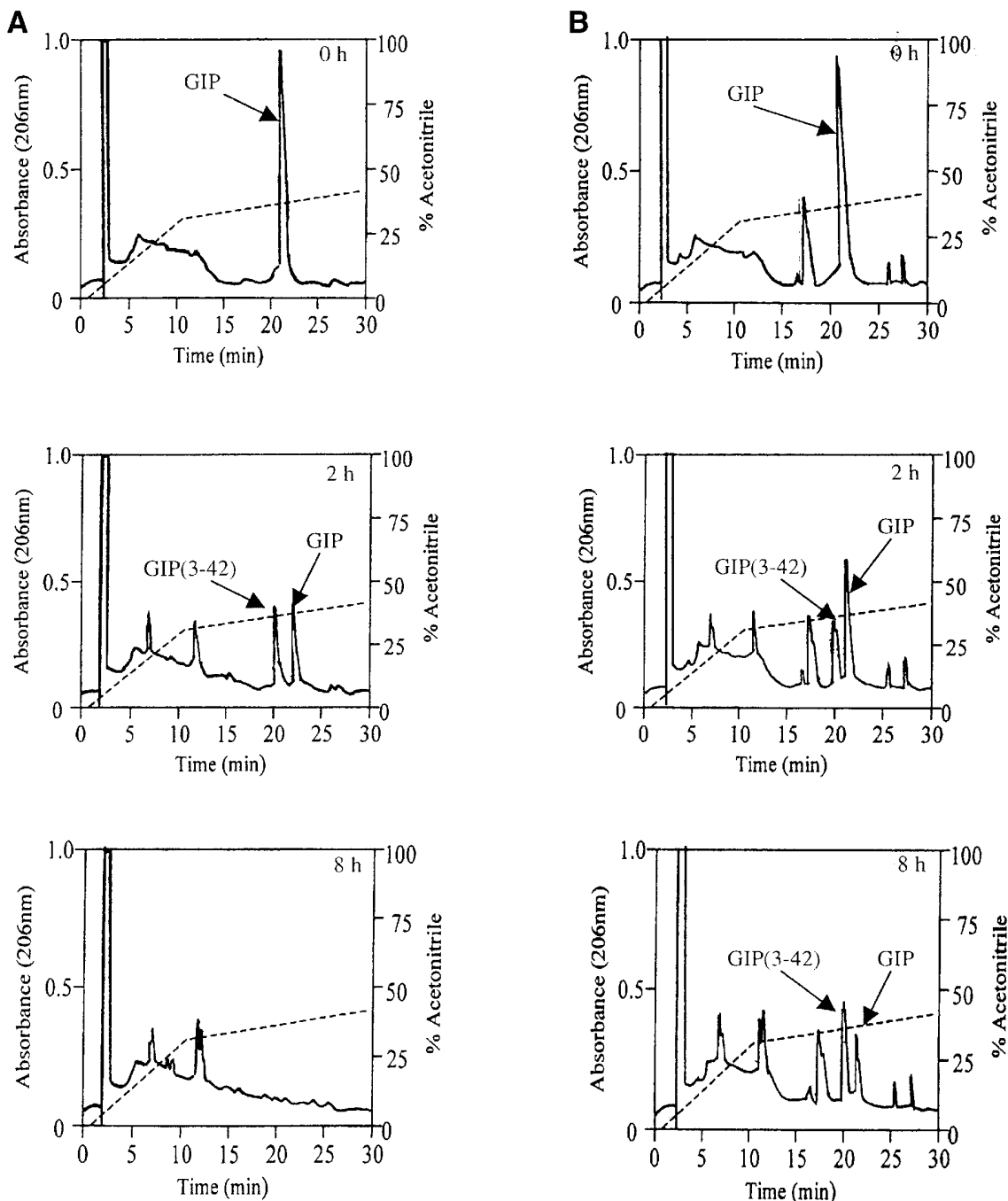

Fig. 2 A, B. Degradation of native GIP by DPP IV and human plasma. Representative HPLC profiles obtained after incubation of native GIP with DPP IV (A) and human plasma (B) for 0, 2 and $8 \mathrm{~h}$. Reaction products were separated on a Vydac C-18 column. HPLC peaks corresponding to intact GIP and GIP(3-42) are indicated

GIP in CHL cells transfected with human GIP receptors. The calculated $\mathrm{EC}_{50}$ values for these peptides were $18.2,1.9$ and $2.7 \mathrm{nmol} / 1$, respectively. The maximal cAMP response of Ac-GIP and pGlu-GIP were $165.7 \pm 1.3$ and $183.9 \pm 5.7 \%,(p<0.001$ and $p<0.001$, respectively), compared to native GIP (100\%).

Effects of GIP, Ac-GIP and pGlu-GIP on insulin secretion. Figure 6 shows the effect of a range of concentrations $\left(10^{-13}\right.$ to $\left.10^{-8} \mathrm{~mol} / \mathrm{l}\right)$ of GIP, Ac-GIP and pGluGIP on insulin secretion from BRIN-BD11 cells. GIP, Ac-GIP and pGlu-GIP stimulated insulin secretion $\left(p<0.01\right.$ to $p<0.001$ ) between $10^{-12}$ and $10^{-8} \mathrm{~mol} / \mathrm{l}$ by 1.2-fold to 2.5 -fold compared to control $(5.6 \mathrm{mmol} / \mathrm{l}$ glucose alone). The ability of native GIP to stimulate insulin secretion was evident at concentrations of

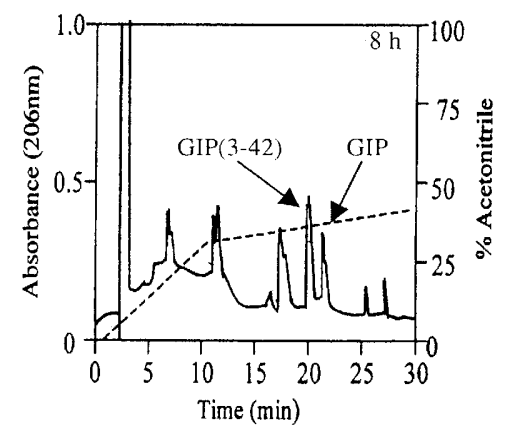

$10^{-11} \mathrm{~mol} / \mathrm{l}$ or higher. Both Ac-GIP and pGlu-GIP were more potent at stimulating insulin secretion $(p<0.05$ to $p<0.001)$ over the entire concentration range tested compared to native GIP. At $10^{-8} \mathrm{~mol} / \mathrm{l} \mathrm{Ac-GIP}$ and pGlu-GIP had a 1.3-fold and 1.2-fold greater stimulatory ability $(p<0.001)$ compared to native GIP.

Effects of GIP, Ac-GIP and pGlu-GIP on antihyperglycaemic activity in (ob/ob) mice. Plasma glucose responses were evaluated after i.p. injection of saline $(0.9 \%(\mathrm{w} / \mathrm{v}) \mathrm{NaCl})$ as a control, glucose alone (18 mmol/kg body weight) or in combination with GIP, Ac-GIP or pGlu-GIP (25 nmol/ $/ \mathrm{kg})$. When saline alone was injected no effect was observed on plasma glucose concentration (Fig. 7A). Administration of glucose alone prompted a high rise $(34.4 \pm 2.9 \mathrm{mmol} / \mathrm{l})$ in plasma glucose $(p<0.001)$ at 15 min compared to basal glucose $(5.4 \pm 0.5 \mathrm{mmol} / \mathrm{l})$, and the plasma glucose concentration declined over the following $45 \mathrm{~min}$ (Fig. 7A). The peak glucose response to native GIP was reduced $(p>0.05)$ at 15 min compared to glucose alone and this failed to reach significance in terms of overall glucose excursion as identified by area under the curve (AUC, 0-60 min, Fig 7B). In contrast both 

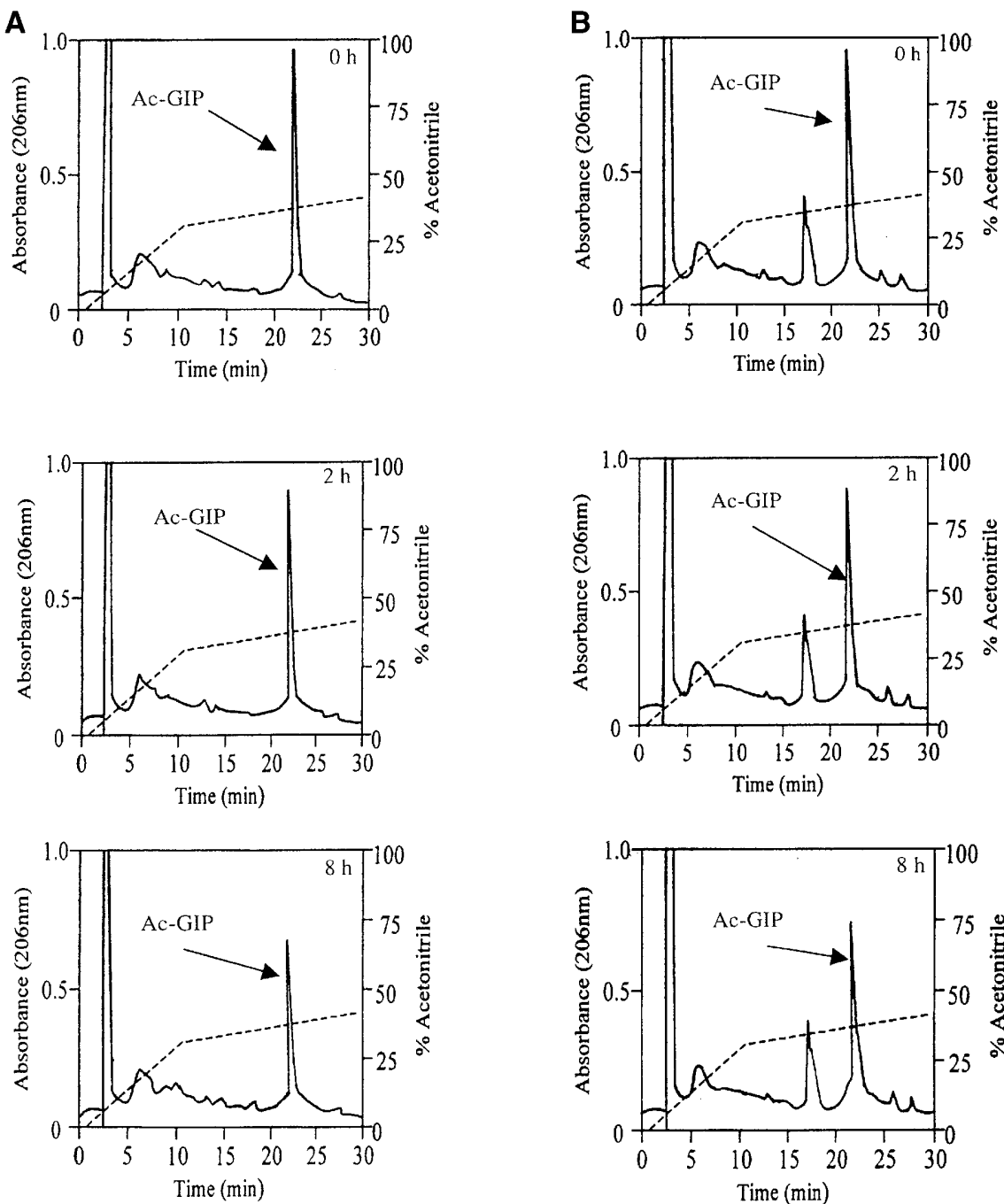

Fig. 3 A, B. Degradation of N-acetyl-GIP by DPP IV and human plasma. Representative HPLC profiles obtained after incubation of Ac-GIP with DPP IV (A) and human plasma (B) for 0, 2 and $8 \mathrm{~h}$. Reaction products were separated on a Vydac C-18 column. HPLC peaks corresponding to intact Ac-GIP are indicated

Ac-GIP and pGlu-GIP reduced the peak 15 to $30 \mathrm{~min}$ glucose excursion compared to glucose alone $(p<0.01$ and $p<0.001)$ and also reduced the AUC $(p<0.05$ and $p<0.01)$ compared to native GIP.

Effects of GIP, Ac-GIP and pGlu-GIP on insulin-releasing activity in ob/ob mice. Plasma insulin responses to administration of saline, glucose and GIP peptides are shown in Fig. 7. Saline had no effect on plasma insulin concentrations (Fig. 7C). Glucose alone caused a peak $(9.0 \pm 0.6 \mathrm{ng} / \mathrm{ml})$ in plasma insulin at 15 min compared to basal insulin $(2.8 \pm 0.5 \mathrm{ng} / \mathrm{ml})$, and the plasma insulin concentration fell over the following $45 \mathrm{~min}$ returning to basal values. The insulin response to GIP in the presence of glucose was greater than to glucose alone as shown by the increase AUC

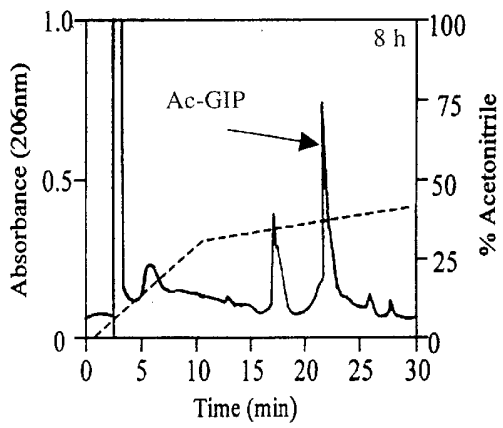

values for insulin over $60 \mathrm{~min}$ (Fig. 7D, $p<0.05$ ). The insulinotropic effects of both Ac-GIP and pGlu-GIP were higher than native GIP at 15,30 and $60 \mathrm{~min}$ $(p<0.001)$. The AUC values showed a substantial enhancement of insulin releasing activity compared to both glucose alone and native GIP (Fig. 7D, $p<0.001$ ). It was notable that the insulinotropic effect of these two novel analogues was much more protracted than that of GIP with plasma insulin remaining higher $(11.8 \pm 0.8$ to $10.9 \pm 0.9 \mathrm{ng} / \mathrm{ml}$, respectively) at $60 \mathrm{~min}$ $(p<0.001)$ compared with native GIP $(3.8 \pm 0.4 \mathrm{ng} / \mathrm{ml})$ (Fig. 7C).

\section{Discussion}

In humans, incretin hormones only stimulate glucoseinduced insulin release under hyperglycaemic conditions $[6,36,37]$ and thus unlike other current non-endogenous insulinotropic agents that are used in the treatment of Type II diabetes, the incretins are not likely to result in hypoglycaemic episodes. It is this unique feature which has led to recent interest in the incretin hormones as a potential therapy for diabetes 

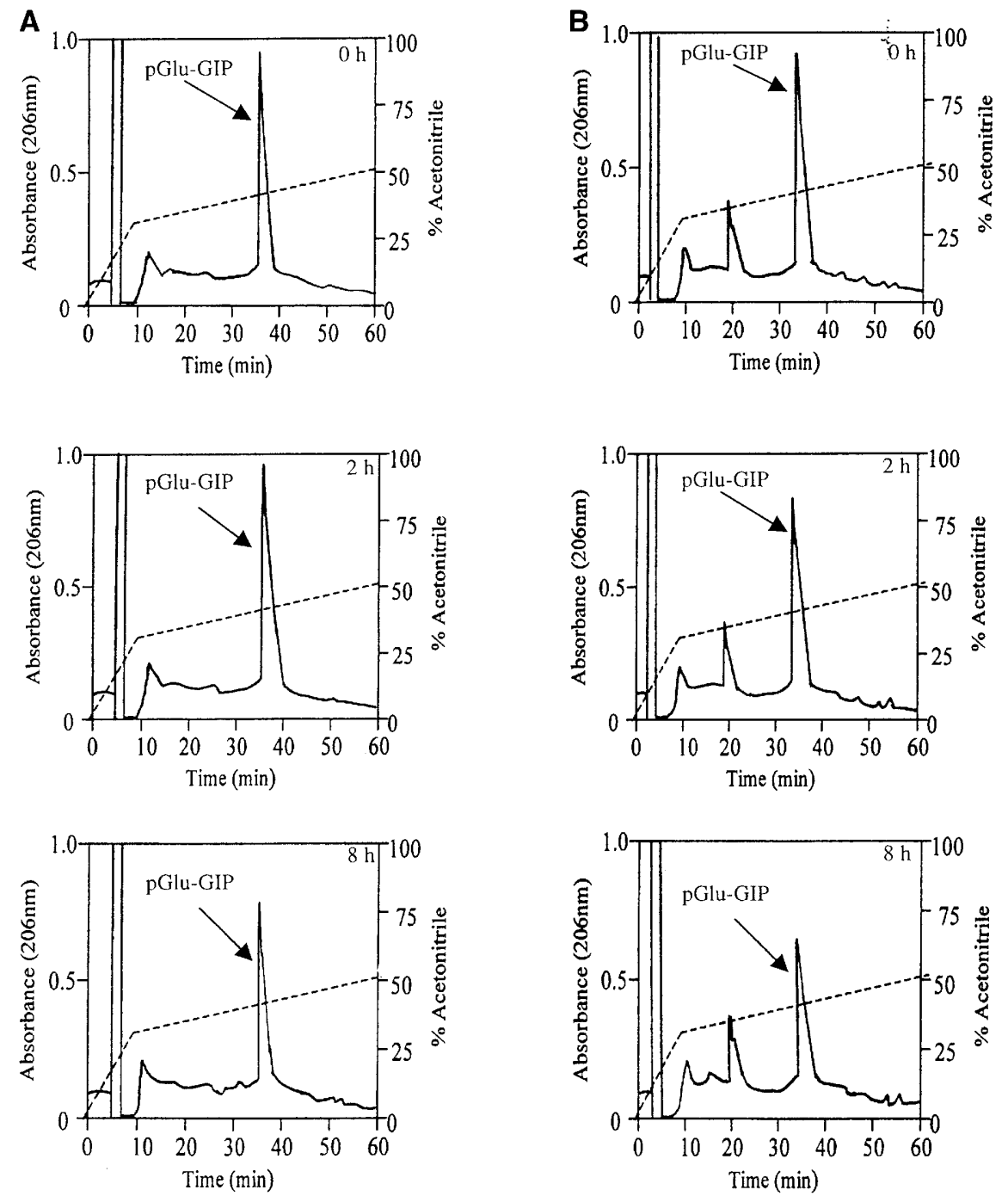

Fig. 4 A, B. Degradation of N-pyroglutamyl-GIP by DPP IV and human plasma. Representative HPLC profiles obtained after incubation of pGlu-GIP with DPP IV (A) and human plasma (B) for 0,2 and $8 \mathrm{~h}$. Reaction products were separated on a Vydac C18 column. HPLC peaks corresponding to intact pGlu-GIP are indicated

$[7,33,38]$. Clinical trials have been restricted to GLP1 [33] but the administration of long-acting peptide analogues of both GLP-1 [38] and GIP [27], as well as specific inhibition of DPP IV [39, 40], have been shown to improve glucose tolerance in experimental animal studies. Although certain groups of Type II diabetic patients have been suggested to show a de-

Fig. 5. Dose-dependent production of intracellular cAMP by GIP, $\mathrm{N}$-acetyl-GIP and N-pyroglutamyl-GIP upon binding to CHL fibroblast cells transfected with the human GIP receptor. Each experiment was carried out in triplicate and the data are expressed in absolute values and represent means \pm SEM of three indepen-
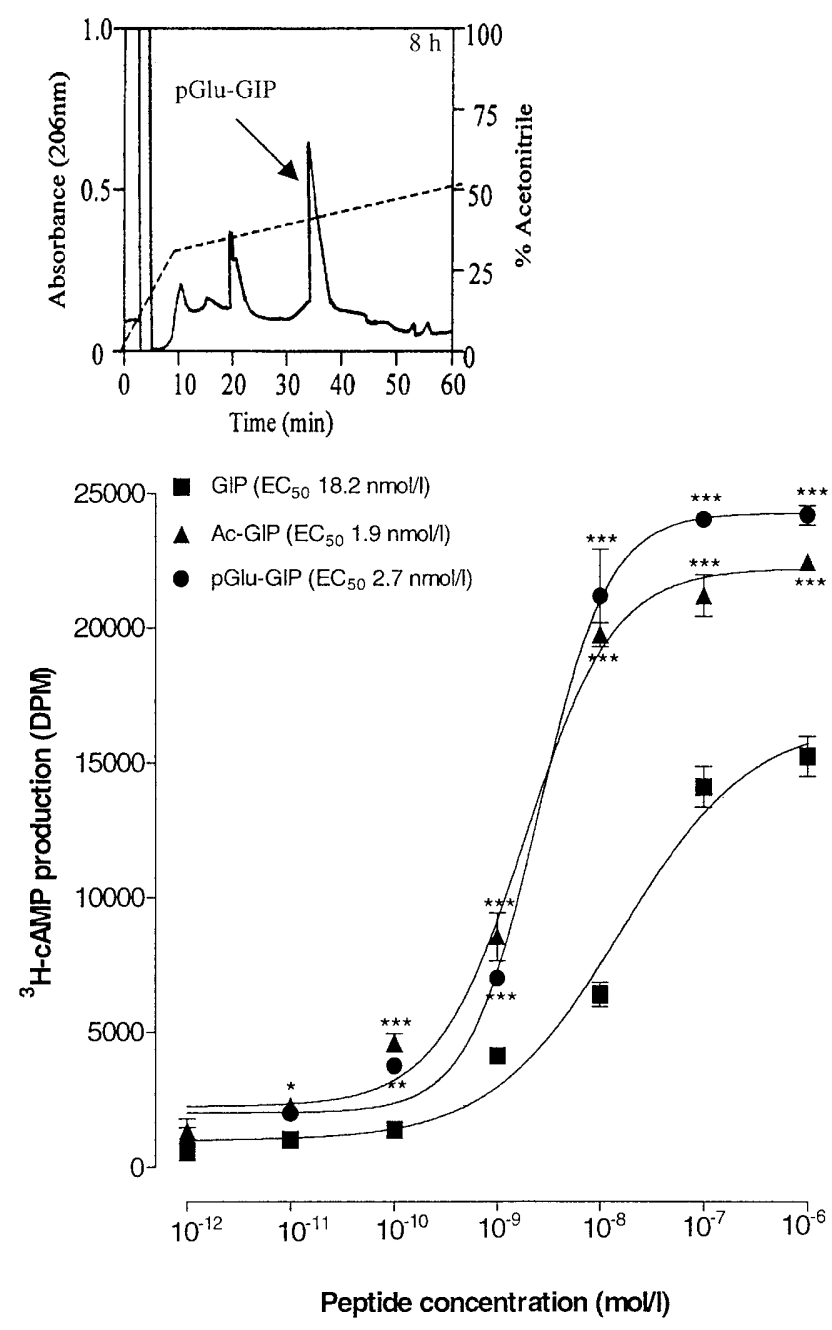

dent experiments. The $\mathrm{EC}_{50}$ values for cAMP production are shown in parentheses 


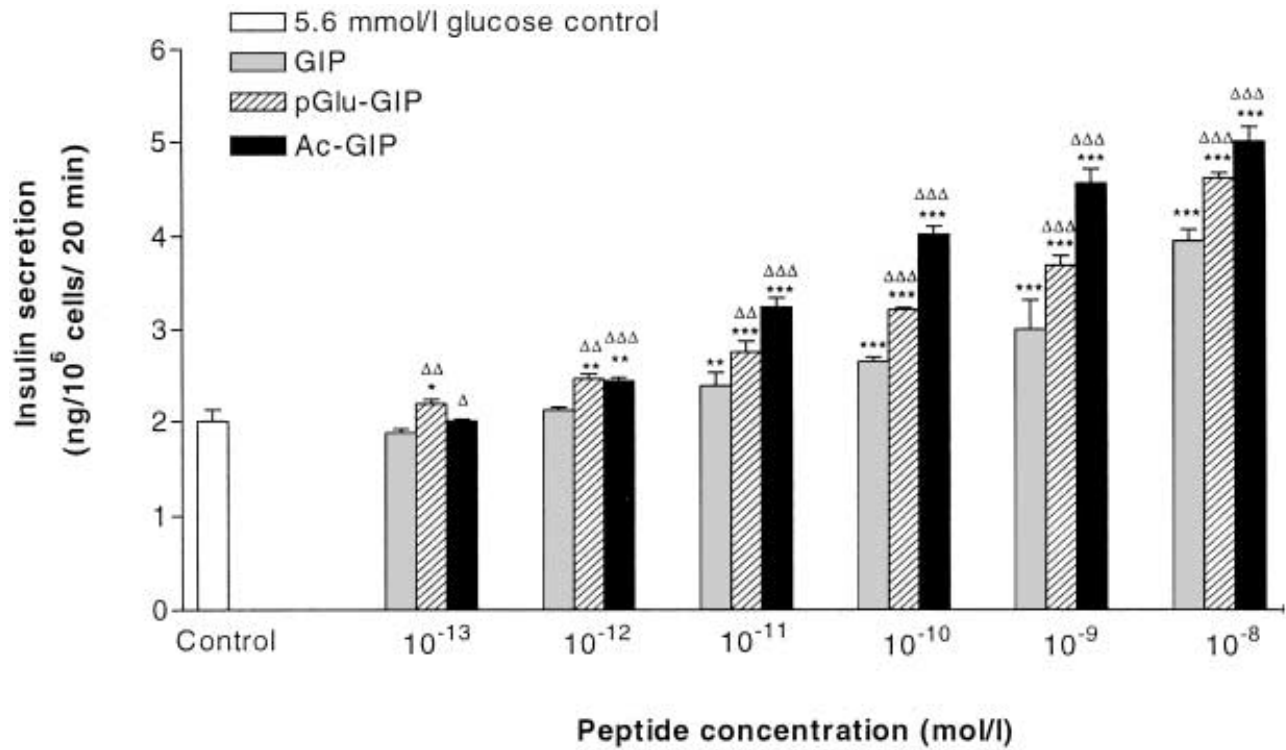

Fig. 6. Dose-dependent effects of GIP, N-acetyl-GIP and N-pyroglutamyl-GIP on insulin secretion from BRIN-BD11 cells. After a pre-incubation of $40 \mathrm{~min}$, the effects of various concentrations of peptide $\left(10^{-13}\right.$ to $\left.10^{-8} \mathrm{~mol} / \mathrm{l}\right)$ were tested on insulin release during

a $20 \mathrm{~min}$ incubation period. Values are means \pm SEM for eight separate observations. $* p<0.05, * * p<0.01, * * * p<0.001$ compared to control (5.6 mmol/l glucose alone). ${ }^{\Delta} p<0.05, \Delta \Delta_{p}<0.01$, $\Delta^{\Delta \Delta \Delta} p<0.001$ compared to GIP at the same concentration

\section{A Plasma glucose $(\mathrm{mmol} \cdot \mathrm{l})$}

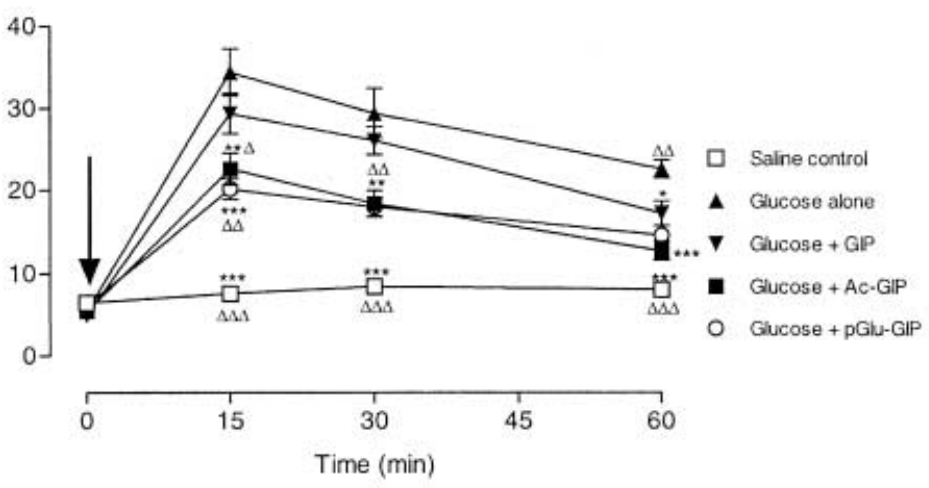

C Plasma insulin (ng.ml)

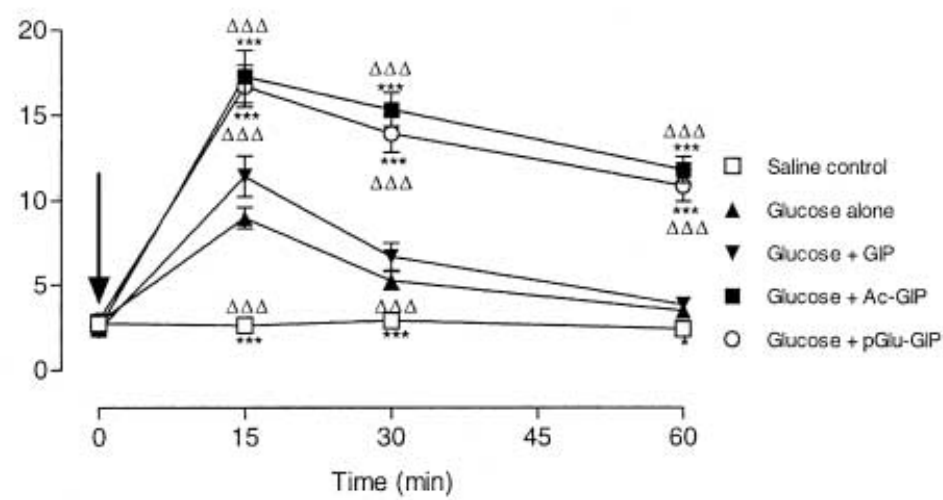

B Glucose $\mathrm{AUC}\left(\mathrm{mmol} \cdot \mathrm{l}^{-1} \cdot \mathrm{min}\right)$

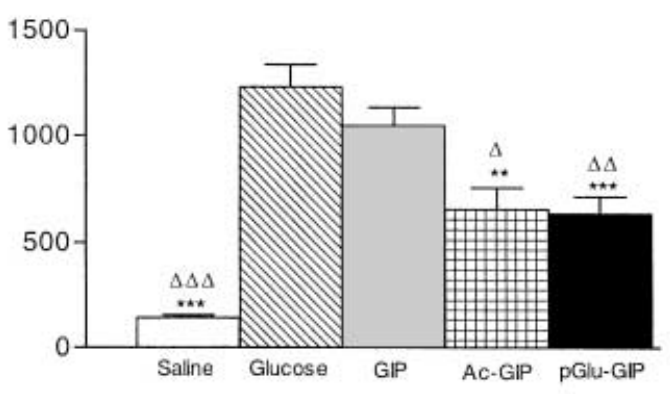

Fig. 7 A-D. Effects of GIP, N-acetyl-GIP and N-pyroglutamylGIP on plasma glucose homeostasis and plasma insulin responses in obese diabetic $(o b / o b)$ mice. A Plasma glucose concentrations were measured prior to and after i.p. administration of saline $(0.9 \%(\mathrm{w} / \mathrm{v}) \mathrm{NaCl})$ as control, glucose alone $(18 \mathrm{mmol} / \mathrm{kg}$ body weight), or in combination with either GIP, Ac-GIP or pGlu-GIP ( $25 \mathrm{nmol} / \mathrm{kg}$ body weight). B Plasma glucose AUC values for 0-60 min post-injection. C Plasma insulin concentrations were measured prior to and after i.p. administration of saline $(0.9 \%$ (w/v) $\mathrm{NaCl}$ ), glucose alone (18 mmol/kg body weight), or in combination with either GIP, Ac-GIP or pGlu-GIP $(25 \mathrm{nmol} / \mathrm{kg}$ body weight). D Plasma insulin AUC values for 0-60 min post-injection. Values are means \pm SEM for eight mice. $* p<0.05, * * p<0.01$, $* * * p<0.001$ compared to glucose alone. ${ }^{\Delta} p<0.05, \Delta \Delta p<0.01$, $\Delta \Delta \Delta_{p}<0.001$ compared to native GIP 
creased beta-cell responsiveness to GIP [41, 42], intracellular pathways triggered by the two incretin hormones seem identical [43]. Mutations of GIP receptors are rare in diabetes $[42,44]$ and any speculated abnormalities in GIP receptor binding could be overcome by stable and structurally modified analogues of GIP. Therefore, GIP analogues could be useful in the treatment of diabetes, and it is important to explore their actions and potential therapeutic value.

DPP IV has been identified as the key enzyme responsible for inactivation of GIP in serum [24]. This inactivation occurs through the rapid removal (GIP half-life 3-5 min) of the N-terminal dipeptide $\mathrm{Tyr}^{1}$ $\mathrm{Ala}^{2}$ giving rise to the major metabolite GIP(3-42). However, DPP IV which has a preference for cleavage after penultimate Pro and Ala residues [19], is responsible for the inactivation of a wide range of other biologically active molecules, such as GLP-1, GLP-2, enterostatin, growth-hormone-releasing factor and neuropeptide Y [20]. Thus inhibitors of DPP IV not only preserve the biological activity of GLP-1 and GIP but also run the risk of adversely affecting many other physiological inactivation processes involving this enzyme [20]. Our study has shown that N-terminal modification of GIP with addition of N-acetyl and N-pyroglutamyl groups confers profound resistance to plasma DPP IV degradation. Thus N-acetyl- and N-pyroglutamyl-GIP were completely stable during in vitro incubations with human serum or purified DPP IV for periods of up to $24 \mathrm{~h}$. As shown elsewhere native GIP was rapidly degraded to $\operatorname{GIP}(3-42)$ by a process prevented by DPA, and thus attributable to DPP IV [15, 22, 24, 27]. The current approach to prolonging GIP activity by structurally modifying the peptide by addition of an N-terminal acetyl or pyroglutamyl group therefore seems to be a more subtle and highly effective method of achieving hormone stability, compared with using non-specific DPP IV inhibitors.

The glucose dependency of the insulinotropic action of GIP has been shown in humans $[36,37]$. Using the glucose clamp technique in humans, others [37] found that mild hyperglycaemia (at least $1.4 \mathrm{mmol} / \mathrm{l}$ above basal levels) was sufficient to initiate the insulinotropic action of GIP. In the perfused rat pancreas, GIP stimulated insulin release at a threshold of $5.5 \mathrm{mmol} / \mathrm{l}$ glucose and a maximal response at $16 \mathrm{mmol} / \mathrm{l}$ glucose [45]. In our study, the insulinotropic effects of GIP and GIP analogues became apparent at about $10^{-11} \mathrm{~mol} / \mathrm{l}$. This is close to the fasting GIP concentration of $5 \times 10^{-11} \mathrm{~mol} / \mathrm{l}$, which rises to $2.5 \times 10^{-10} \mathrm{~mol} / 1$ after ingestion of a mixed meal [46, 47]. Evaluation of the activities of N-acetyl-GIP and $\mathrm{N}$-pyroglutamyl-GIP to increase cAMP showed that these N-terminally modified GIP analogues were up to tenfold more potent than the native hormone. Furthermore, GIP analogues increased insulin secretion up to threefold over glucose alone which compares to a maximal 1.6-fold increase over basal in response to sulphonylureas under similar conditions [48]. This cannot be attributed to differences in the degradation of GIP peptides in acute tests as this was negligible. Thus the results raise the possibility that enhancement of potency at the GIP receptor could overcome any natural impairment of GIP stimulation in diabetes. Of interest, these effects were observed at a physiological glucose concentration of $5.6 \mathrm{mmol} / \mathrm{l}$, providing much encouragement for heightened biological activity in vivo.

Consistent with the in vitro studies, administration of Ac-GIP or pGlu-GIP improved the antihyperglycaemic and insulin-releasing activity of the peptide when administered with glucose to obese diabetic $(o b / o b)$ mice. Native GIP only modestly increased plasma insulin and reduced the glycaemic excursion in the diabetic mutant as observed in several studies $[49,50]$. However, the N-terminal Tyr ${ }^{1}$-modified analogues of GIP increased the insulin-releasing and antihyperglycaemic actions of the peptide by on average 2.4-fold and 1.9-fold, respectively, as estimated from AUC measurements. Detailed kinetic analysis, however, is difficult due to the limitation of sampling times, but the prolonged insulin response after administration of the $\mathrm{N}$-terminal $\mathrm{Tyr}^{1}$-modified analogues as opposed to GIP is also indicative of a longer half-life. Thus these in vivo results suggest that N-acetyl and N-pyroglutamyl analogues of GIP show resistance to DPP IV degradation while at the same time evoking an enhanced stimulatory insulin secretory response from the beta cell. The former action will impede degradation of the peptide to $\operatorname{GIP}(3-42)$, thereby prolonging the half-life and enhancing effective circulating concentrations of the biologically active peptide. It will also decrease circulating concentrations of GIP(3-42) which functions as a highly selective GIP antagonist [51, 52]. Based on these results, it seems that these novel $\mathrm{N}$-terminal $\mathrm{Tyr}^{1}$-modified analogues of GIP enhance insulin secretion in vivo and improve glycaemic responses in Type II diabetes by conferring DPP IV resistance as well as increased potency at the GIP receptor. Moreover GIP has been proposed to exert various extrapancreatic effects, which could contribute to anthyperglycaemic activity in vivo including stimulation of peripheral glucose uptake $[16,53,54$, 55].

In conclusion, this study shows that the N-terminal $\mathrm{Tyr}^{1}$-modified analogues of GIP, N-acetyl-GIP and Npyroglutamyl-GIP, show strong resistance to DPP IV, and thereby have an extended plasma half-life, which in turn contributes to the enhanced biological activity in vitro. This is accompanied by improved antihyperglycaemic activity and raised insulin concentrations in vivo. These observations greatly encourage further investigation of the possible use of stable and biologically enhanced GIP analogues, alongside of those for GLP-1, for the treatment of diabetes and alleviation of its complications. 
Acknowledgements. These studies were supported by University of Ulster Research Strategy Funding. The authors wish to thank Professor B. Thorens (University of Lausanne, Switzerland) for kindly providing the transfected Chinese hamster lung fibroblast (CHL) cells.

\section{References}

1. Östenson CG (2001) The pathophysiology of Type II diabetes mellitus: an overview. Acta Physiol Scand 171: 241-247

2. Pratley RE, Weyer C (2001) The role of impaired early insulin secretion in the pathogenesis of Type II diabetes mellitus. Diabetologia 44: 929-945

3. Brown JC (1994) Enteroinsular axis. In: Walsh J, Dockray $\mathrm{G}$ (eds) Gut peptides biochemistry and physiology. Raven Press, New York, pp 765-784

4. Habener JF (1993) The incretin notion and its relevance to diabetes. Endocrinol Metab Clin North Am 22: 775-794

5. Gutniack M, Ørskov C, Holst JJ, Ahren B, Effendic S (1992) Antidiabetic effect of glucagon-like peptide-1 (7-36)amide in normal subjects and patients with diabetes mellitus. N Eng J Med 326: 1316-1322

6. Holst JJ (2000) Gut hormones as pharmaceuticals. From enteroglucagon to GLP-1 and GLP-2. Regul Pept 93: 45-51

7. Creutzfeldt W (2001) The entero-insular axis in type 2 diabetes-incretins as therapeutic agents. Exp Clin Endocrinol Diabetes 109: S288-S303

8. Suzuki S, Kawai K, Ohashi S, Watanabe Y, Yamashita K (1992) Comparison of the insulinotropic activity of the glucagon-superfamily peptides in rat pancreas perfusion. Horm Metab Res 24: 458-461

9. Shima K, Hirota M, Ohboshi C (1988) Effect of glucagonlike peptide-1 on insulin secretion. Regul Pept 22: 245-252

10. Siegel EG, Schulze A, Schmidt WE, Creutzfeldt W (1992) Comparison of the effect of GIP and GLP-1 (7-36)amide on insulin release from rat pancreatic islets. Eur J Clin Invest 22: $154-157$

11. Jia X, Brown JC, Ma P, Pederson RA, McIntosh CHS (1995) Effects of glucose-dependent insulinotropic polypeptide and glucagon-like peptide-1-(7-36) on insulin secretion. Am J Physiol 268: E645-E651

12. Pederson RA, Satkunarajah M, McIntosh CHS et al. (1998) Enhanced glucose-dependent insulinotropic polypeptide secretion and insulinotropic action in glucagon-like peptide 1 receptor -/- mice. Diabetes 47: 1046-1052

13. Miyawaki K, Yamada Y, Yano H et al. (1999) Glucose intolerance caused by a defect in the entero-insular axis: a study in gastric inhibitory polypeptide receptor knockout mice. Proc Nat Acad Sci USA 96: 14843-14847

14. Jones IR, Owens DR, Moody AJ, Luzio SD, Morris T, Hayes TM (1987) The effects of glucose-dependent insulinotropic polypeptide infused at physiological concentrations in normal subjects and Type II (non-insulin-dependent) diabetic patients on glucose tolerance and B-cell secretion. Diabetologia 30: 707-712

15. Kieffer TJ, McIntosh CHS, Pederson RA (1995) Degradation of glucose-dependent insulinotropic polypeptide and truncated glucagon-like peptide 1 in vitro and in vivo by dipeptidyl peptidase IV. Endocrinology 136: 3585-3596

16. Fehmann HC, Göke R, Göke B (1995) Cell and molecular biology of the incretin hormones glucagon-like peptide-1 and glucose-dependent insulin releasing polypeptide. Endocr Rev 16: 390-410
17. Barrett AJ, Rawlings ND (1992) Oligopeptidases, and the emergence of the prolyl oligopeptidase family. Biol Chem 373: 353-360

18. Wrenger S, Faust J, Mrestani-Klaus C et al. (2000) Down regulation of T-cell activation following inhibition of dipeptidyl peptidase IV/CD26 by the N-terminal part of the thromboxane A2 receptor. J Biol Chem 275: 22180-22186

19. Walter R, Simmons WH, Yoshimoto T (1980) Proline-specific endo-and exopepidases. Mol Cell Biochem 30: 111-127

20. Mentlein R (1999) Dipeptidyl-peptidase IV (CD26)-role in the inactivation of regulatory peptides. Regul Pept 85: 9-24

21. Lojda Z (1979) Studies on dipeptidyl(amino)peptidase IV (glycyl-proline naphthylamidase) II Blood vessels. Histochemistry 59: 153-166

22. Mentlein R, Gallwitz B, Schmidt WE (1993) Dipeptidylpeptidase IV hydrolyses gastric inhibitory polypeptide, glucagon-like peptide-1(7-36)amide, peptide histidine methionine and is responsible for their degradation in human serum. Eur J Biochem 214: 829-835

23. Maletti M, Carlquist M, Portha B, Kergoat M, Mutt V, Rosselin G (1986) Structural requirements for gastric inhibitory polypeptide (GIP) receptor binding and stimulation of insulin release. Peptides 7: 75-78

24. Deacon CF, Danielsen P, Klarskov L, Olesen M, Holst JJ (2001) Dipeptidyl peptidase IV inhibition reduces the degradation and clearance of GIP and potentiates its insulinotropic and antihyperglycaemic effects in anesthetized pigs. Diabetes 50: 1588-1597

25. O'Harte FPM, Mooney MH, Kelly CM, Flatt PR (2000) Improved glycaemic control in obese diabetic ob/ob mice using N-terminally modified gastric inhibitory polypeptide. J Endocrinol 165: 639-648

26. O'Harte FPM, Mooney MH, Kelly CM, McKillop AM, Flatt PR (2001) Degradation and glycemic effects of His7glucitol glucagon-like peptide-1(7-36)amide in obese diabetic ob/ob mice. Regul Pept 96: 95-104

27. O'Harte FPM, Mooney MH, Flatt PR (1999) N-terminally modified gastric inhibitory polypeptide exhibits aminopeptidase resistance and enhanced antihyperglycaemic activity. Diabetes 48: 758-765

28. Fields GB, Noble RL (1990) Solid phase peptide synthesis utilizing 9-fluorenylmethoxycarbonyl amino acids. Int J Pept Protein Res 35: 161-214

29. Gremlich S, Porret A, Hani EH et al. (1995) Cloning, functional expression, and chromosomal localization of the human pancreatic islet glucose-dependent insulinotropic polypeptide receptor. Diabetes 44: 1202-1208

30. McClenaghan NH, Barnett CR, Ah-Sing E et al. (1996) Characterization of a novel glucose-responsive insulin-secreting cell line, BRIN-BD11, produced by electrofusion. Diabetes 45: 1132-1140

31. Bozou JC, Amar S, Vincent JP, Kitabgi P (1986) Neurotensin-mediated inhibition of cyclic AMP formation in neuroblastoma N1E115 cells: involvement of the inhibitory GTP-binding component of adenylate cyclase. Mol Pharmacol 29: 489-496

32. Flatt PR, Bailey CJ (1981) Abnormal plasma glucose and insulin responses in heterozygous lean $(o b /+)$ mice. Diabetologia 20: 573-577

33. Bailey CJ, Flatt PR (1995) Development of antidiabetic drugs. In: Ioannides C, Flatt PR (eds) Drugs, diet and disease: mechanistic approaches to diabetes. Ellis Horwood, London, pp 279-326

34. Stevens JF (1971) Determination of glucose by automatic analyser. Clin Chem Acta 32: 199-201

35. Burington RS (1973) Handbook of mathematical tables and formulas. McGraw-Hill, New York 
36. Dupré J, Ross SA, Watson D, Brown JC (1973) Stimulation of insulin secretion by gastric inhibitory polypeptide in man. J Clin Endocrinol Metab 37: 826-828

37. Elahi D, Andersen DK, Brown JC (1979) Pancreatic $\alpha$ and $\beta$-cell responses to GIP infusion in normal man. Am J Physiol 237: E185-E191

38. Holst JJ (1999) Glucagon-like peptide-1; a gastrointestinal hormone with pharmaceutical potential. Curr Med Chem 6: 1005-1017

39. Pederson RA, White HA, Schlenzig D, Pauly RP, McIntosh CH, Demuth H-U (1998) Improved glucose tolerance in Zucker fatty rats by oral administration of the dipeptidyl peptidase IV inhibitor isoleucine thiazolidide. Diabetes 47: 1253-1258

40. Pauly RP, Demuth H-U, Rosche F et al. (1999) Improved glucose tolerance in rats treated with the dipeptidyl peptidase IV (CD26) inhibitor ile-thiazolidide. Metabolism 48: 385-389

41. Nauck MA, Heimesaat MM, Ørskov C, Holst JJ, Ebert R, Creutzfeldt W (1993) Preserved incretin activity of glucagon-like peptide 1 [7-36 amide] but not of synthetic human gastric inhibitory polypeptide in patients with type- 2 diabetes mellitus. J Clin Invest 91: 301-307

42. Elahi D, McAloon-Dyke M, Fukagawa NK et al. (1994) The insulinotropic actions of glucose dependent insulinotropic polypeptide (GIP) and glucagon-like peptide-1 (7-37) in normal and diabetic subjects. Regul Pept 51: 63-74

43. Ding WG, Gromada J (1997) Protein kinase A-dependent stimulation of exocytosis in mouse pancreatic beta-cells by glucose-dependent insulinotropic polypeptide. Diabetes 46: 615-621

44. Almind K, Ambye L, Urhammer SA et al. (1998) Discovery of amino acid variants in the human glucose-dependent insulinotropic polypeptide (GIP) receptor: the impact on the pancreatic beta cell responses and functional expression studies in Chinese hamster fibroblast cells. Diabetologia 41: 1194-1198

45. Pederson RA, Brown JC (1976) The insulinotropic action of gastric inhibitory polypeptide in the perfused isolated rat pancreas. Endocrinology 99: 780-789
46. Rasmussen H, Zawalich KC, Ganesan S, Calle R, Zawalich WS (1990) Physiology and pathophysiology of insulin secretion. Diabetes Care 13: 655-666

47. Gama R, Norris F, Morgan L, Hampton S, Wright J, Marks V (1997) Elevated post-prandial gastric inhibitory polypeptide concentrations in hypertriglyceridaemic subjects. Clin Sci (Colch) 93: 343-347

48. McClenaghan NH, Ball AJ, Flatt PR (2001) Specific desensitization of sulfonylurea- but not imidazoline-induced insulin release after prolonged tolbutamide exposure. Biochem Pharmacol 61: 527-536

49. Flatt PR, Bailey CJ, Kwasowski P, Page T, Marks V (1984) Plasma immunoreactive gastric inhibitory polypeptide in obese hyperglycaemic $(o b / o b)$ mice. J Endocrinol 101: 249-256

50. Flatt PR, Kwasowski P, Howland RJ, Bailey CJ (1991) Gastric inhibitory polypeptide and insulin responses to orally administered amino acids in genetically obese hyperglycemic (ob/ob) mice. J Nutr 121: 1123-1128

51. Deacon CF, Nauck MA, Meier J, Hucking K, Holst JJ (2000) Degradation of endogenous and exogenous gastric inhibitory polypeptide in healthy and in type 2 diabetic subjects as revealed using a new assay for the intact peptide. J Clin Endocrinol Metab 85: 3575-3581

52. Gelling RW, Coy DH, Pederson RA et al. (1997) GIP(6-30amide) contains the high affinity binding region of GIP and is a potent inhibitor of GIP1-42 action in vitro. Regul Pept 69: 151-154

53. Chap Z, Ishida T, Chou J, Lewis R, Hartley C, Entman M, Field JB (1985) Effects of atropine and gastric inhibitory polypeptide on hepatic glucose uptake and insulin extraction in conscious dogs. J Clin Invest 76: 1174-1181

54. Hartmann H, Ebert R, Creutzfeldt W (1986) Insulin-dependent inhibition of hepatic glycogenolysis by gastric inhibitory polypeptide (GIP) in perfused rat liver. Diabetologia 29: 112-114

55. O'Harte FPM, Gray AM, Flatt PR (1998) Gastric inhibitory polypeptide and effects of glycation on glucose transport and metabolism in isolated mouse abdominal muscle. J Endocrinol 156: 237-243 